\title{
Pengaruh Kompensasi Finansial, Gaya Kepemimpinan, dan Motivasi Kerja Terhadap Kinerja Karyawan pada Perusahaan Manufaktur di Jawa Timur
}

\author{
Slamet Riyadi \\ Fakultas Ekonomi, Universitas 17 Agustus 1945 \\ E-mail: slametriyadi08@yahoo.com
}

\begin{abstract}
This study aims to determine the relationship between financial compensation, leadership style and motivation to the employee's performance of manufacture's company. The respondents were managers of middle management at manufacture's company as much as 110 people chosen randomly from the sampling frame amounted to 152. Data is collected using the instrument in the form of questionnaires. The instrument is calibrated using the validity of items and reliability coefficient. Data were analyzed using Structural Equation Modeling (SEM) with PLS Smart package. The results show that: (1) there is no influence of financial compensation (X1) on work motivation (Z), (2) leadership style (X2) has a positive influence on motivation (Z) significantly, (3) there is no influence of financial compensation (X1) on the employee's performance $(Y)$, (4) leadership style (X2) has a positive and significant influence on the employee's performance (Y), and (5) work motivation $(Z)$ directly have a significant positive influence on the employee's performance $(Y)$. These findings have implications that financial compensation does not significantly influence the work motivation and employee's performance. Leadership styles significantly influence workers' motivation and employee's performance. Work motivation influences employee's performance. Leadership is an important factor in providing direction to the employee especially at this present moment in which transparency becomes essential. The leadership that is needed is leadership that can empower their employees. Leadership that can motivate employees is leadership that can foster a sense of confidence of the employees in carrying out their duties.
\end{abstract}

Keywords: financial compensation, leadership style, motivation, employee’s performance

\section{PENDAHULUAN}

Dalam era persaingan usaha yang semakin ketat, kinerja yang dimiliki karyawan dituntut untuk terus meningkat. Salah satu langkah untuk mempertahankan atau meningkatkan kinerja karyawan dapat dilakukan dengan mengevaluasi kinerja karyawan dan melakukan serangkaian perbaikan agar selalu meningkatkan kualitas karyawan tersebut sehingga perusahaan tumbuh dan unggul dalam persaingan, atau minimal tetap dapat bertahan.

Timpe (1992) mengungkapkan kinerja adalah tingkat prestasi seseorang atau karyawan dalam suatu organisasi atau perusahaan yang dapat meningkatkan produktifitas. Terdapat dua faktor yang dapat mempengaruhi kinerja karyawan yaitu faktor internal dan faktor eksternal. Faktor internal merupakan faktor yang berhubungan dengan sifat-sifat seseorang, meliputi sikap, sifat-sifat kepribadian, sifat fisik, keinginan atau motivasi, umur, jenis kelamin, pendidikan, pengalaman kerja, latar belakang budaya dan variabel-variabel personal lainnya. Faktor eksternal merupakan faktor-faktor yang mempengaruhi kinerja karyawan yang berasal dari lingkungan, kepemimpinan, tindakan-tindakan rekan kerja, jenis latihan dan pengawasan, sistem upah dan lingkungan sosial.

Motivasi memiliki hubungan yang erat dengan sikap dan perilaku yang dimiliki oleh seseorang. Sikap yang ada pada setiap individu berinteraksi dengan nilai-nilai, emosi, peran, struktur sosial dan peristiwa-peristiwa baru, yang bersama-sama emosi dapat dipengaruhi dan diubah oleh perilaku. Perubahan sikap ini dimungkinkan karena pikiran manusia adalah suatu kekuatan kompleks yang dapat mengadaptasi, mempelajari, dan memproses setiap informasi dan perubahan baru yang diterimanya. Motivasi itu sendiri dapat diartikan sebagai keadaan dalam diri pribadi seseorang sehingga orang tersebut terdorong untuk melakukan suatu kegiatan atau aktivitas. Oleh karenanya, motivasi mempunyai sifat yang tidak akan lepas dari sifat manusia itu sendiri, dimana manusia secara individual mempunyai kualitas eksistensi diri yang berbeda-beda antara satu dengan yang lainnya. Tiap-tiap individu mempunyai latar belakang dan sikap yang berbeda terhadap rangsangan yang ada, sehingga motivasi yang muncul pada tiap-tiap individu pun berbeda-beda. Beberapa cara dapat digunakan para pemimpin untuk memberikan motivasi positif terhadap bawahannya, seperti pengharga- 
an terhadap pekerjaan yang dilakukan, penghargaan khusus secara pribadi, kompetisi, partisipasi, kebanggaan atau kepuasan dan materi.

Dalam konteks perusahaan, Handoko (2001) mengemukakan bahwa suatu cara untuk meningkatkan prestasi kerja, motivasi dan kepuasan kerja karyawan adalah dengan memberikan kompensasi. Hasibuan (2006) menyatakan kompen-sasi adalah semua pendapatan yang berbentuk uang, barang langsung atau tidak langsung yang diterima karyawan sebagai imbalan atas jasa yang diberikan kepada perusahaan. Lebih lanjut Sikula yang diterjemahkan Mangkunegara (2005), mengatakan kompensasi adalah pemberian upah yang merupakan imbalan, pembayaran untuk pelayanan yang telah diberikan oleh karyawan.

Kompensasi mencakup semua jenis pembayaran baik secara langsung maupun tidak langsung, berbentuk materil/uang maupun penghargaan yang diberikan perusahaan kepada pekerja/buruhnya. Penelitian ini mengambil satu jenis kompensasi yakni pembayaran langsung berbentuk finansial yang disebut dengan upah.

Salah satu elemen yang bernilai penting dalam sistem manajemen perusahaan selain motivasi kerja dan kompensasi adalah kepemimpinan (leadership). Kepemimpinan adalah suatu proses dimana seseorang dapat menjadi pemimpin (leader) melalui aktivitas yang terus menerus sehingga dapat mempengaruhi yang dipimpinnya (followers) dalam rangka mencapai tujuan organisasi atau perusahaan. Hubungan antara seorang pemimpin maupun yang dipimpin merupakan suatu proses kepemimpinan karena leader needs followers and followers needs leader. Meskipun leader dan followers saling terkait, namun para pemimpin seharusnya yang seringkali berinisiatif menjalin hubungan, komunikasi dan memelihara hubungan sehingga tujuan perusahaan sebagaimana yang telah dirumuskan dalam visi, misi, rencana dan strategi perusahaan dapat tercapai.

\section{KAJIAN TEORITIS}

Kompensasi adalah semua pendapatan yang berbentuk uang, barang langsung atau tidak langsung yang diterima karyawan sebagai imbalan atas jasa yang diberikan kepada perusahaan Hasibuan (2006). Handoko (2001) mengemukakan bahwa kompensasi penting bagi karyawan dan individu karena besarnya kompensasi mencerminkan ukuran nilai karya mereka diantara karyawan sendiri, keluarga dan masyarakat.

Menurut Simamora (2006) pada umumnya komponen kompenasi dapat dibagi menjadi kom- pensasi langsung (direct compensation) dan kompensasi tidak langsung (indirect compensation). Kompensasi finansial langsung (direct financial compensation) terdiri dari bayaran (pay) yang diperoleh seseorang dalam bentuk gaji, upah, bonus. Kompensasi finansial tidak langsung (indirect financial compensation) yang disebut dengan tunjangan meliputi semua imbalan finansial yang tidak tercakup dalam kompensasi langsung. Kompensasi non finansial (nonfinancial compensation) terdiri atas kepuasan kerja yang diperoleh seseorang dari pekerjaan itu sendiri atau dari lingkungan psikologis di mana orang itu bekerja. Tipe kompensasi non finansial meliputi kepuasan yang didapat dari pelaksanaan tugas yang signifikan yang berhubungan dengan pekerjaan.

Pemberian kompensasi dalam suatu organisasi harus diatur sedemikian rupa sehingga merupakan sistem yang baik dalam organisasi (Simamora, 2006). Perusahaan memberikan kompensasi dengan harapan adanya rasa timbal balik dari karyawan tersebut untuk bekerja dengan prestasi yang baik. Hasibuan (2006) menyatakan bahwa kompensasi yang diterapkan dengan baik akan memberikan motivasi kerja bagi karyawan. Kompensasi yang diberikan harus layak, adil, dapat diterimakan, memuaskan, memberi motivasi kerja, bersifat penghargaan dan sesuai dengan kebutuhan (Lewa \& Subowo, 2005). Pemberian kompensasi akan memberikan manfaat kepada kedua belah pihak, baik kepada pihak perusahaan maupun kepada pihak karyawan.

Kepemimpinan menurut Terry dalam Davis (1985) "Leadership is the relationship in which one person, or the leader, influences others to work togethet willingly on related tasks to attain that which the leader desires", kepemimpinan adalah proses mendorong dan membantu orang lain untuk bekerja dengan antusias guna mencapai tujuan.

Nasution (1994) mengemukakan bahwa seorang pemimpin harus mengembangkan suatu gaya dalam memimpin bawahannya. Suatu gaya kepemimpinan dapat dirumuskan sebagai suatu pola perilaku yang dibentuk untuk diselaraskan dengan kepentingankepentingan organisasi dan karyawan untuk dapat mencapai tujuan yang telah ditetapkan.

Thoha (2007) mengemukakan ada beberapa gaya kepemimpinan, diantaranya adalah gaya kepemimpinan situasional, yaitu gaya yang didasarkan pada saling berhubungannya hal-hal berikut ini: 1) jumlah petunjuk dan pengarahan yang diberikan oleh pimpinan, 2) jumlah dukungan emosional yang diberikan oleh pimpinan, 3) tingkat kesiapan atau kematangan para pengikut dalam melaksanakan tugas khusus, fungsi atau tujuan tertentu. 
Menurut teori kontingensi dari Fiedler dalam Sujak (1990), kepemimpinan yang berhasil bergantung pada penerapan gaya seorang pemimpin terhadap tuntutan situasi. Aplikasi gaya kepemimpinan, dalam proses adaptasi terhadap situasi dapat menempuh suatu proses: 1) memahami gaya kepemimpinannya, 2) mendiagnosa suatu situasi, dan 3) menerapkan gaya kepemimpinan yang relevan dengan tuntutan situasi.

Teori kepemimpinan situasional yang dikembangkan oleh Robert House yang disebut the path goal theory dalam kutipan Sujak (1990) mengemukakan pada teori "pengharapan" dalam motivasi yang menyatakan bahwa orang akan termotivasi oleh dua harapan berupa kemampuannya untuk mengerjakan suatu tugas dan rasa percayanya bahwa jika pegawai tersebut dapat mengerjakan tugas dengan baik akan memperoleh hadiah yang berharga bagi dirinya. Menurut House, bila pemimpin memberi dorongan yang lebih besar terhadap pemenuhan harapan tersebut, maka semakin besar pula prestasi yang akan diperoleh para pegawainya. House dalam Sujak (1990) mengemukakan empat gaya kepemimpinan yang menjadi perilaku seorang pemimpin yaitu: 1) kepemimpinan yang berorientasi pada prestasi, 2) kepemimpinan direktif, 3) kepemimpinan partisipatif, 4) kepemimpinan suportif.

Teori yang dikemukakan oleh House ini menyatakan bahwa antara pemimpin dengan bawahan dituntut komunikasi yang efektif, berupa dorongan dari pemimpin kepada pegawainya dalam mempertemukan antara tugas-tugas yang akan dikerjakan bawahan dengan harapan-harapan yang ada pada pemimpin.

Kepemimpinan situasional menggunakan dua dimensi kepemimpinan yang sama seperti dikenali oleh Fiedler: perilaku tugas dan hubungan. Tetapi Hersey dan Blanchard (1982) melangkah lebih jauh dengan mempertimbangkan masing-masing dimensi sebagai tinggi atau rendah dan kemudian menggabungkan semuanya menjadi empat perilaku pemimpin yang spesifik: memberitahukan, menjual, berperan serta, dan mendelegasikan (telling, selling, participating, delegation).

Gaya kepemimpinan berpengaruh signifikan dan positif terhadap kinerja karyawan (Fadli, 2004). Gaya kepemimpinan yang baik akan berdampak pada kinerja karyawan yang tinggi. Penelitian yang dilakukan Smat (2005) menunjukkan bahwa gaya kepemimpinan berpengaruh positif dan signifikan terhadap motivasi kerja karyawan.

Motivasi kerja menurut Gibson et al. (1997) adalah kekuatan yang mendorong seorang karyawan yang menimbulkan dan mengarahkan perilaku.
Motivasi merupakan hasrat di dalam seseorang yang menyebabkan orang tersebut melakukan tindakan.

Wahyusumidjo (1987) menyatakan bahwa motivasi merupakan daya dorong sebagai hasil proses interaksi antara sikap, kebutuhan, dan persepsi bawahan dari seseorang dengan lingkungan, motivasi timbul diakibatkan oleh faktor dari dalam dirinya sendiri disebut faktor instrinsik, dan faktor yang dari luar diri seseorang disebut faktor ekstrinsik.

Teori yang mendasari kajian penelitian ini adalah teori Motivasi Kebutuhan untuk berprestasi. McClelland et al. (1953) mengambil teori asalnya dengan konsep motif prestasi yang dikemukakan oleh Murray pada tahun 1938. Teori ini penekanannya pada keperluan peringkat tinggi, yang menyatakan bahwa individu yang tinggi motivasi berprestasi akan menunjukkan keutamaan yang tinggi kepada situasi yang sederhana, yaitu kemungkinan derajat mencapai keberhasilan dan kegagalan adalah sama. Sebaliknya orang-orang yang rendah motivasi berprestasinya suka kepada situasi yang sangat sukar atau sangat mudah mencapai keberhasilan (Atkinson \& Birch, 1978; McClelland, 1961).

McClelland (1961) memberi ciri-ciri yang ada pada individu yang mempunyai motivasi berprestasi/ pencapaian yang tinggi, yaitu: a) suka membuat kerja yang berkaitan dengan prestasi, b) suka mengambil risiko yang sederhana, c) lebih suka membuat kerja yang mana individu itu bertanggungjawab bagi keberhasilan kerja itu, d) suka mendapat kemudahan tentang kerja itu, e) lebih mementingkan masa depan daripada masa sekarang dan masa yang telah lalu, dan f) tabah apabila menemui kegagalan. Sifat-sifat tersebut dikatakan sebagai puncak yang membedakan seseorang. Seorang individu lebih berhasil daripada individu yang lain karena mereka mempunyai keinginan pencapaian yang lebih tinggi. Keinginan ini memberi mereka motivasi untuk bekerja dengan lebih tekun (McClelland et al., 1953).

Selanjutnya, McClelland (1961) menyatakan bahwa motivasi berprestasi/pencapaian bukan sesuatu yang diwariskan. Disebabkan pengaruh situasi disekitarnya, maka motivasi berprestasi/pencapaian boleh dibentuk mengikut cara tertentu. Davis \& Newstroom (1985:88) mendefinisikan motivasi berprestasi (achievement motivation) adalah dorongan dalam diri orang-orang untuk mengatasi segala tantangan dan hambatan dalam upaya mencapai tujuan. Penelitian yang dilakukan Hernowo dan Farid menunjukkan bahwa terdapat pengaruh yang signifikan dan positif antara variabel motivasi terhadap kinerja pegawai BKD Kabupaten Wonogiri.

Kinerja adalah suatu hasil kerja yang dicapai seorang dalam melaksanakan tugas-tugas yang di- 
bebankan kepadanya yang didasarkan atas kecakapan, pengalaman dan kesungguhan serta waktu (Hasibuan, 2006). Kinerja seseorang merupakan ukuran sejauh mana keberhasilan seseorang dalam melakukan tugas pekerjaannya. Ada 3 (tiga) faktor utama yang berpengaruh pada kinerja yaitu individu (kemampuan bekerja), usaha kerja (keinginan untuk bekerja), dan dukungan organisasional (kesempatan untuk bekerja). Kinerja seseorang dipengaruhi oleh beberapa faktor seperti: ability, capacity, held, incentive, environment dan validity (Notoatmodjo, 1992).

Penilaian kinerja adalah proses suatu organisasi mengevaluasi atau menilai kerja karyawan. Apabila penilaian prestasi kerja dilaksanakan dengan baik, tertib, dan benar akan dapat membantu meningkatkan motivasi berprestasi sekaligus dapat meningkatkan loyalitas para anggota organisasi yang ada di dalamnya, dan apabila ini terjadi akan menguntungkan organisasi itu sendiri. Oleh karena itu penilaian kinerja perlu dilakukan secara formal dengan kriteriakriteria yang telah ditetapkan oleh organisasi secara obyektif.

Simamora (2006), penilaian kinerja adalah alat yang berfaedah tidak hanya untuk mengevaluasi kerja dari para karyawan, tetapi juga untuk mengembangkan dan memotivasi kalangan karyawan. Dalam penilaian kinerja tidak hanya semata-mata menilai hasil fisik, tetapi pelaksanaan pekerjaan secara keseluruhan yang menyangkut berbagai bidang seperti kemampuan, kerajinan, disiplin, hubungan kerja atau hal-hal khusus sesuai bidang tugasnya semuanya layak untuk dinilai.

Berdasarkan pemaparan-pemaparan yang yang dituangkan dalam teori maupun penelitian terdahulu, maka dapat diungkapkan bahwa kinerja karyawan tidak lepas dari motivasi kerja karyawan, dimana motivasi kerja karyawan tersebut dipengaruhi kompensasi finansial yang diperoleh karyawan dan gaya kepemimpinan dari atasan yang dirasakan oleh karyawan. Lebih jelas dari ungkapan tersebut disajikan dalam bentuk kerangka konseptual penelitian berikut ini:

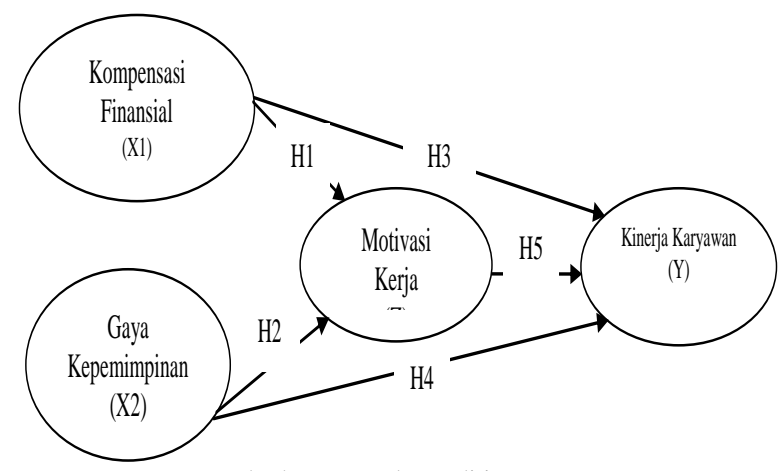

Keterangan: Kerangka konseptual penelitian
Berdasarkan kerangka penelitian tersebut, maka disampaikan hipotesis berikut:

$\mathrm{H} 1$ : Kompensasi finansial berpengaruh signifikan terhadap motivasi kerja.

$\mathrm{H} 2$ : Gaya kepemimpinan berpengaruh signifikan terhadap motivasi kerja.

H3: Kompensasi finansial berpengaruh signifikan terhadap kinerja karyawan.

H4: Gaya kepemimpinan berpengaruh signifikan terhadap kinerja karyawan.

H5 : Motivasi kerja mempunyai berpengaruh signifikan terhadap kinerja karyawan.

\section{METODE PENELITIAN}

Populasi dalam penelitian ini adalah para manajer tingkat menengah yang bekerja di Perusahaan Manufaktur yang ada di wilayah Jawa Timur, berdasarkan kriteria yang ditentukan peneliti, maka anggota populasi sejumlah 152 manajer, sedangkan responden yang digunakan sebagai sampel menggunakan rumus yang dikemukakan Slovin yaitu,

$$
n=\frac{N}{N\left(d^{2}\right)+1}
$$

dengan tingkat akurasi tingkat ketepatan (d) $5 \%$, sehingga responden yang diolah lebih lanjut sejumlah 110 manajer.

Pengumpulan data dilakukan dengan menyebarkan kuesioner ke para responden. Kuesioner terdiri dari 4 variabel, yaitu: 1) Variabel Kompensasi dengan 6 item pertanyaan, 2) Variabel Kepemimpinan dengan 7 item, 3) Variabel Motivasi dengan 8 item, dan 4) Variabel Kinerja karyawan sejumlah 8 item. Masing-masing item tersebut menggunakan skala lickert dengan rentang jawaban 1 sampai 5 .

\section{HASIL DAN PEMBAHASAN}

Teknik analisis data dalam penelitian ini menggunakan SPSS untuk pengujian kuesioner yaitu uji validitas dan reliabilitas, sedangkan untuk menguji pengaruh masing-masing variabel menggunakan Structural Equation Modeling (SEM) dengan paket Smart PLS. Uji validitas dilakukan dengan melihat nilai loading factor masing-masing indikator yang ada di 4 variabel yang diteliti, hasil menunjukkan bahwa nilai loading factor dari masing-masing indikator tersebut diatas 0,5 dengan tingkat signifykansi 5\%, hal ini berarti bahwa masing-masing indikator adalah valid (construct validity, alat ukur terpenuhi). Sedangkan untuk Uji Reliabilitas menggunakan nilai composite variable dengan ketentuan besarnya dari nilai tersebut harus lebih besar dari 0,6 (composite reliability > 0,6). Hasil uji reliabilitas 
menunjukkan bahwa masing-masing variabel memiliki nilai composite variable diatas 0,6 , sehingga dapat disimpulkan bahwa seluruh indikator/alat ukur adalah relialibel dan dapat digunakan untuk analisa selanjutnya.

Pengujian selanjutnya dilakukan untuk mengetahui apakah ada pengaruh antar variabel laten yang telah di hipotesiskan sebelumnya. Hasil pengujian dapat dilihat pada Tabel 1

Tabel 1. Koefisien Jalur Regresi

\begin{tabular}{ccccc}
\hline No $\quad$ Variabel & $\begin{array}{c}\text { Regression } \\
\text { Weight } \\
\text { (Standardized) }\end{array}$ & T-Statistic & $\begin{array}{c}\text { Keterangan } \\
\text { (T-Statistic >1,96) }\end{array}$ \\
\hline 1. $\mathrm{X} 1 \rightarrow \mathrm{Z}$ & 0,060 & 0,283 & Tidak Signifikan \\
2. $\mathrm{X} 2 \rightarrow \mathrm{Z}$ & 0,489 & 3,652 & Signifikan \\
3. $\mathrm{X} 1 \rightarrow \mathrm{Y}$ & $-0,154$ & 0,792 & Tidak Signifikan \\
4. $\mathrm{X} 2 \rightarrow \mathrm{Y}$ & 0,294 & 2,623 & Signifikan \\
5. $\mathrm{Z} \rightarrow \mathrm{Y}$ & 0,540 & 4,293 & Signifikan \\
\hline \multicolumn{2}{l}{ Sumber: Hasil olahan PLS } & &
\end{tabular}

$\mathrm{X} 1$ : Kompensasi Finansial

$\mathrm{X} 2$ : Gaya Kepemimpinan

$\mathrm{Z}$ : Motivasi Kerja

$\mathrm{Y}:$ Kinerja Karyawan

Pengujian hipotesis dilakukan dengan membandingkan nilai t-statistik pada setiap variabel laten dengan t-tabel $(1,96)$, yaitu dikatakan signifikan jika tstatistik variabel laten lebih besar dari 1,96.

Setelah dilakukan penelitian dan menganalisa data yang didapat dari responden untuk menguji hipotesis, maka hasil penelitian dapat dijabarkan berikut:

1. Hasil pengujian menunjukkan bahwa variabel bebas kompensasi finansial (X1) tidak berpengaruh terhadap motivasi kerja (Z), hal ini ditunjukkan dengan nilai t-statistik sebesar 0,283, dimana nilai ini dibawah nilai t-tabel $(1,96)$. Hasil penelitian ini menolak atau tidak mendukung hipotesis 1.

2. Hipotesis 2 didukung oleh hasil penelitian, yaitu gaya kepemimpinan (X2) secara signifikan mempengaruhi motivasi kerja (Z), hal ini didukung dengan nilai t-statistic diatas 1,96 yaitu sebesar 3,652. Hasil ini mendukung teori maupun penelitian terdahulu.

3. Hasil penelitian tidak mendukung hipotesis 3 , karena nilai t-statistic sebesar 0,792 dibawah ttabel $(1,96)$, hal ini berarti bahwa kompensasi finansial (X1) tidak mempengaruhi kinerja karyawan $(\mathrm{Y})$.

4. Hasil penelitian mendukung hipotesis 4, yaitu gaya kepemimpinan (X2) secara signifikan mempengaruhi Kinerja Karyawan $(\mathrm{Y})$ dengan nilai tstatistic diatas t-tabel $(1,96)$ yaitu sebesar 2,623.
5. Motivasi Kerja (Z) secara signifikan mempengaruhi Kinerja Karyawan $(Z)$ dengan nilai tstatistic 4,293, hasil ini mendukung pernyataan yang diungkap di hipotesis 5 .

6. Terkait dengan hasil penelitian untuk hipotesis 1 dan hipotesis 3 yang menunjukkan bahwa kompensasi finansial tidak berpengaruh terhadap motivasi kerja maupun kinerja karyawan, hal ini dapat terjadi kemungkinan disebabkan karena responden yang dipilih para manajer yang berada di tingkat menengah, dalam kondisi seperti ini harapan dari masing-masing responden bukan semata-mata kompensasi finansial yang dituju melainkan kompensasi non finansialpun dapat menjadi pertimbangan dalam meningkatkan motivasi maupun kinerja karyawan, karena pada umumnya kompensasi finansial yang diterima para responden sesuai atau bahkan melebihi harapan responden.

\section{KESIMPULAN}

Penelitian ini ditujukan untuk menguji pengaruh kompensasi finansial, gaya kepemimpinan, dan motivasi terhadap kinerja karyawan. Penelitian dilakukan dengan menggunakan 110 responden yang berasal dari manajer menengah yang bekerja di perusahaan manufaktur yang ada di wilayah Jawa Timur. Hasil penelitian menunjukkan bahwa kompensasi finansial tidak mempengaruhi motivasi kerja maupun kinerja karyawan. Sedangkan gaya kepemimpinan secara signifikan mempengaruhi motivasi kerja maupun kinerja karyawan, dan motivasi kerja secara signifikan mempengaruhi kinerja karyawan.

\section{DAFTAR PUSTAKA}

Atkinson, J. W. \& D. Birch. 1978. Introduction to Motivation, New York: D. Van Nostrand Company.

Casio, Wayne F. 1995. Managing Human Resources: Productivity, Quality of Work Life, Profit, Singapore: McGraw-Hill International Editors.

Davis, Keith \& John W. Newstroom. 1985. Perilaku Dalam Organisasi, Alih Bahasa: Agus Dharma, Jakarta: Erlangga.

Djati, S. Pantja \& M Khusaini. 2003. "Kajian Terhadap Kepuasan Kompensasi, Komitmen Organisasi dan Prestasi Kerja", Jurnal Manajemen dan Kewirausahaan, Universitas Kristen Petra. http://fportfolio.petra.ac.id /main.php? nip=91 akses 14 Mei 2010.

Fadli, Ahmad. 2004. "Pengaruh Gaya Kepemimpinan Terhadap Kinerja Karyawan PT. Kawasan 
Industri Medan", Thesis, Universitas Sumatera Utara. http://library.usu.ac.id/download/ fe/tesis-ahmad\%20fadli.pdf akses 19 Juli 2010.

Gibson, Ivancevich, Donnely. 1997. Organizations (Terjemahan), Cetakan Keempat, Jakarta: PT. Gelora Aksara Pratama.

Handoko, T. Hani. 2001. Manajemen Personalia dan Sumber Daya Manusia, Yogyakarta: Penerbit Andi.

Hasibuan, Malayu S.P. 2006 Manajemen Sumber Daya Manusia, Jakarta: PT Haji Masagung.

Hernowo \& M. Farid Wajdi tentang "Pengaruh Motivasi dan Disiplin Terhadap Kinerja Pegawai Badan Kepegawaian Kabupaten Wonogiri" http://eprints.ums.ac.id/790/2/Jurnal_Daya_Saing_1_1.pdf

Hersey, Paul \& Ken Blancard. 1982. Management of Organizational Behaviour, New Jersey: Prentice Hall Inc. Englewood Cliffs.

Lewa, Eka Idham lip K. \& Subowo. 2005. "Pengaruh Kepemimpinan, Lingkungan Kerja Fisik dan Kompensasi Terhadap Kinerja Karyawan di PT Pertamina (Persero) Daerah Operasi Hulu Jawa Bagian Barat, Cirebon”, Jurnal Sinergi Kajian Bisnis dan Manajemen. http://journal. uii.ac.id/index.php/Sinergi/article/view/934 akses 29 Juni 2010.

Luthan, Fred. 2006. Organizational Behavior, $10^{\text {th }}$ Edition, Alih Bahasa: Vivin Andika Yuwono, Shekar Purwanti, Th. Arie P dan Winong Rosari, Yogyakarta: Penerbit Andi.

Mangkunegara AA. Anwar Prabu. 2005. Manajemen Sumber Daya Perusahaan, Bandung; PT. Remaja Rosda Karya.

Manullang, M. \& Marihot Manullang. 1998. Manajemen Sumber Daya Manusia, Yogyakarta: BPFE.
McClelland, D. C., J.W. Atkinson, R.A. Clark \& E.L. Lowell. 1953. The Achievement Motive, Princeton, NJ: Van Nostrand.

McClelland, D. C. 1961. The Achieving Society, Princeton, NJ: Van Nostrand.

Nasution, Mulia. 1994. Manajemen Personalia, Aplikasi dalam Perusahaan, Jakarta: Djambatan.

Notoatmodjo, Soekidjo. 1992. Pengembangan Sumber Daya Manusia, Jakarta: PT. Rineka Cipta.

Robbins, Stephen P. 2003. Perilaku Organisasi, Jakarta: PT. Indeks Kelompok Gramedia.

Ruky, Achmad S. 2002. Sistem Manajemen Kinerja, Jakarta: Gramedia Pustaka Utama.

Simamora, Henry. 2006. Manajemen Sumber Daya Manusia, edisi ketiga, Cetakan kedua, Yogyakarta: Penerbitan STIE YKPN.

Smat, Warsid. 2005. "Pengaruh Gaya Kepemimpinan Terhadap Motivasi Kerja Karyawan Di Kantor Regional VI Badan Kepegawaian Negara (BKN) Medan", Thesis, Universitas Sumatera Utara. http://library.usu.ac.id/ download/fe/tesis-warsid.pdf akses 16 Juni 2010.

Sujak, Abi. 1990. Kepemimpinan Manajer: Eksistensinya dalam Perilaku Organisasi, Jakarta: CV. Rajawali.

Thoha, Miftah. 2007. Kepemimpinan dalam Manajemen: Suatu Pendekatan Perilaku, Jakarta: PT. Raja Grafindo Persada.

Timpe, A. Dale. 1992. The Art and Science of Business Management Performance, Mumbai: Jaico Publishing House.

Wahyusumidjo. 1987. Kepemimpinan dan Motivasi, Jakarta: Galia Indonesia.

Winardi. 1971. Organisasi Perkantoran Modern, Bandung: Alumni. 